Article

\title{
Identity, Commons and Sustainability: An Economic Perspective
}

\author{
Marco Setti * (D) and Matteo Garuti \\ Department of Agricultural and Food Sciences-Viale Fanin 50, Alma Mater Studiorum-University of Bologna, \\ 40127 Bologna, Italy; matteogaruti83@gmail.com \\ * Correspondence: marco.setti@unibo.it
}

Received: 1 December 2017; Accepted: 1 February 2018; Published: 5 February 2018

\begin{abstract}
Commons represent a wide, heterogeneous class of resources but its composition is the subject of growing tensions. The question "What is a commons?" has become even more complex while the answer still remains elusive. Current research focuses on two main attributes of commons-nonexclusivity and rivalry - centered on regulatory and operational aspects, conveying the notion of usability. Instead, this study argues that the definition of commons should be derived from their function. It is proposed that identity, in its individual and collective integrated dimensions, is the ultimate goal of commons. Despite the pivotal function that commons can perform, availability of resources is indeed just one of the conditions for human development. Moreover, commons can deploy their identity-oriented functions only if a sustainability transition is pursued. Based on these considerations, the study analyzes the concept of sustainability, and addresses the question "What is to be sustained?" While the capability approach offers a coherent conceptualization of the diversity of individuals-a crucial issue for sustainability - some limitations arise when it is adopted as evaluative space of well-being. This study argues that the assumed notion of identity delivers a broader concept of sustainability and delineates the ultimate goal of sustainability (sustainable identity).
\end{abstract}

Keywords: identity; commons; common-pool resources; sustainability; capability approach; economics; environment; food

\section{Introduction: The Drift of the Commons}

Common resources (hereafter, commons) embrace a broad spectrum of shared goods and services, from forests to town squares and from knowledge to electricity [1]. Commons are a wide and heterogeneous category of resources that exert a significant and growing influence on individuals and communities' quality of life.

Commons are (or should be) shared resources. From this peculiar condition derives their foremost attribute of-a certain degrees of-openness in their accessibility (i.e., nonexclusivity, nonexcludability, and nondiscrimination), a quality they share with public goods. Moreover, commons are characterized by suffering caused by competition between concerned agents (i.e., rivalry, subtractability, divisibility, capturability, depletability, and exhaustability), a quality they share with private goods and that distinguishes them from public goods [2,3].

To use a metaphor, commons are not adrift in a calm sea. Because of their variety and the pivotal role they play in society, current turbulent and impactful socioeconomic changes affect both the nature of these resources and the composition of the related category. On the one hand, financial and economic crises [4], unregulated competition [5], selfishness [6], and behavioral bias (e.g., time inconsistency and incorrect beliefs) [7] trigger commodification and degradation processes that restrict their availability and use. On the other hand, regulatory mechanisms [3,8,9], new technologies [10], and social norms and preferences $[11,12]$ are some of the drivers that enable an increasing array of new or more widely diffused commons to emerge, such as culture, open software, and relational goods. 
A large body of literature deals with this tidal system and provides concepts and definitions of commons mostly based on the analysis of related property regimes, institutional agreements, and management schemes [2,13-17]. Similarly, economic studies usually identify the nature of these resources through the two mentioned qualities (nonexclusivity and rivalry), again focused on access and use patterns [18-20]. The generality of these research efforts requires a normative approach to be adopted to study commons by assuming their attributes of openness to others and divisibility as privileged keys of analysis. Overall, economic studies insist on regulative and operational elements of the relationships between agents and resources, and convey the notion of usability. Moving from this economic perspective, Section 2 provides an overview of the state of the art on commons from the perspectives of the two conventional characteristics: nondiscriminatory and subtractability.

While the usability-based approach enables analytical depiction of the challenges and opportunities associated with the subject, it can hardly offer comprehensive knowledge or definition of this wide and composite set of resources, let alone an effective narrative of their changing qualities. The question of what a commons is, posed by, among other authors, Hess and Ostrom [18], has become even more complex, while the answer still appears far away.

In this study, it is argued that a descriptive approach can instead provide useful insights into the rough sea of commons. In this regard, this study opts to analyze what this category of resources delivers to individuals and their communities and, therefore, the reason that commons are intended to be open to others and the object of rivalry. Function, rather than access and use, is assumed as the privileged concept to describe these resources.

Based on these concepts, this study is aimed at contributing to the understanding of the economic nature of commons by diagnosing the service they provide to human well-being. Identity-the self-construction process in its individual and collective integrated dimensions [21,22] -is the broad notion of well-being suggested to describe the ultimate goal of the universe of commons and, moreover, to explain the meaning of their two canonical attributes. In particular, the development of personal and social identity requires the fulfillment of two related principles: dignity and membership, respectively [23]. It is argued that any resource pertaining to the category of commons should serve at least one of these identity-based principles. The proposed analysis and interpretation are designed to favor knowledge, definition, and recognition of commons and thus, to provide substantive issues to support their governance (Section 3).

Because commons are conceived as suppliers of crucial functions (dignity and membership) favoring identity building and, then, well-being achievements, this study further explores the overall conditions enabling their performance. Due to the centrality of the envisaged functions, these conditions should be consistent with the principles of justice, the constitutive element of sustainability. With this aim, the study analyzes the wider concept of sustainability and its normative goal, and addresses the related question "What is to be sustained?"

First, it is recognized that justice requires a careful consideration of the diversity of individuals concerning their beliefs, judgments, abilities, objectives, and social context. In this regard, resourcecentered approaches to justice tend to evaluate the situation of individuals in terms of share of available goods and services [24], while individuals are implicitly assumed to be similar. Without accounting for the differences among individuals, the holding of resources-considered alone-would lead to inequality. In particular, a similar condition would be detrimental to the identity-oriented function commons exert. Therefore, this study refers to the alternative exploration of social justice: the capability approach. According to this approach [25,26], endowment of resources is indeed just one of the conditions for fair and durable human development, while a robust conceptualization of the heterogeneity and complexity of human agency is central to the conversion of resources into individual achievements (functionings).

Second, it is stressed that this theoretical framework focused on freedom of choice (capabilities) and functionings encounters some limitations when adopted as an evaluative criterion of quality of life (the terms "well-being," "quality of life," and "lifestyle" are used interchangeably throughout 
this article). Misuse and underuse of freedom of choice overflow from the decisional basin the capability approach provides, and might limit opportunities commons offer to people, and undermine human development.

It is then argued that the assumed notion of identity is coherent with the capability approach, while admitting an expanded informational space for well-being assessments (where not only interindividual differences between individuals, but also intra-individual differences within individuals are considered) and delivering a broader vision of the concept of sustainability (Section 4).

\section{Commons: An Overview}

Most economic studies analyze commons for the purpose of deriving concrete indications of how access should be regulated and use managed [2]. The aim of this resource-centered approach appears motivated not only by the relevant and threatened role commons play, but also by the large variety of this category of resources, implying coherent diversification of regulatory and operational solutions. From this perspective, the two attributes-nonexclusive access and rivalrous use-are assumed the fundamental qualities of commons. While access to commons implies nondiscrimination, the notion of use introduces subtractability concerns as the second distinctive characteristic [18].

Studies focused on subjects related to access mainly explore regulatory frameworks ("commonproperty regime"), whereas research centered on use patterns deals with governing rules ("commonpool institution"), analyzes the interrelations between these two topics $[2,19,27,28]$, and examines institutional and managerial schemes as a whole ("common-pool resources") [2,14,29].

With regard to the "common-property regime" field, the commons' peculiar qualities of being shared resources and open to others have given rise to different interpretations of the concept of property. On the one hand, property has been adopted as the constitutive element of commons, which are identified in this view as a particular form of ownership [30-32]. On the other hand, a number of studies have highlighted how misleading and shortsighted this standpoint can be [2]. In fact, it is stated that nonexclusive access requires appropriate regulation [33], which can be provided by a large set of property regimes [34-36]. The latter thinking yields a clear distinction between common's quality of openness to users and accessibility schemes [29,37]. The variety of patterns controlling the possibilities to access to commons [13,38], which is further widened by the growing diffusion of global digital goods available to anyone [1,28,39], entails the design of suitable governing arrangements and rules ("common-pool institution" and "common-pool resources"). Ibele et al. [12], for instance, show that exogenously imposed allocation rules are less effective than endogenous rule-crafting due to the role of behavioral and cultural norms in controlling free-riding behavior.

In particular and differently from the public goods realm [18], institutional agreements and management schemes are required to deal with commons' crucial technical characteristic of being intrinsically divisible. According to Ostrom [2] (p. 644), this attribute can lead not only to "rivalry of consumption" but also, when rules fail to govern usage, to subtraction and exhaustion of resources. While rivalry can further manifest its negative repercussions in congestion when commons are asymmetrically used (as in the case of open commons, such as infrastructure and town squares $[13,39]$ ), authors identify additional physical and technical attributes that differentiate some particular commons (e.g., renewability and visibility) and influence their users' choices. For instance, Schlager et al. [40] analyze the relevant role that mobility flows and storage capacity might play when dealing with commons, such as water basins and fisheries. Feeny et al. [41] underline how the multiple nature of commons is both a cause and an effect of the interactions among resources that the systems manifest.

In addition, Hagedorn [42] argues that natural—and technical—systems (e.g., water, pasture) are relevant mediators of the "nature-related transactions [ ... ] between actors" (p. 585). Owing to the high level of dynamic interconnections among the involved systems, these interactions have huge implications for the governance of commons [43,44]. Moreover, Frank [45] and Vaastrom [46], among other authors, show that contextual conditions as well as scales of intervention (e.g., local and large spatial areas) significantly affect both the understanding of commons and the agents' decisions 
(analyses of the evolution of ideas and management schemes of commons in different historical conditions are contributed by De Moor [14]).

It emerges that the composite category of commons is associated with a number of alternative ways of use and, consequently, that governing bodies, strategies, and rules should be coherently shaped into different and plural settings (e.g., polycentric governance, $[2,8,47])$ and participative schemes [48]. Therefore, resource regime, institutional fit [49,50], and managerial appropriateness must be measured in terms of capacity to face rivalry by supporting coordination among economic actors, balancing and merging interests, implementing analytical but comprehensive solutions and, then, avoiding the overexploitation of resources, as a great deal of experience proves [2].

While divisibility and rivalry are-together with nonexclusivity—the dominant and unifying attributes of the generality of commons, a particular category of resources is characterized by the alternative quality of being relational. The web and social media can favor participation and interpersonal linkages (collaborative commons, [20]). Knowledge, friendship, and commitment enable the development of building reciprocity and relationships (relational goods, [51,52]). Meanwhile, large natural areas can promote sociality and citizenship [16,46,53,54]. The peculiarity of these resources stems from the condition to be used through direct and proactive interpersonal relationships, substantiated by cooperative, collaborative, or altruistic acts (antirivalry, [51,55]). The nature of this particular category of goods and services suggests a triple order of implications for the understanding of commons.

First, commons can belong to the class of relational resources. For example, food can produce conviviality, natural resources can offer opportunities for socialization [56], and cultural goods and knowledge can deliver inclusivity [10]. In other words, relational commons can lose their specific attribute of rivalry. Second, according to recent studies, it can be argued by extension, and reversely, that social relations and practices can trigger processes that generate commons ("commonings", $[17,31,57,58])$. Thus, commons can merge resources and social values, such as responsibility and civic participation [15,59]. Third, the social-based quality that defines relational and collaborative goods stems from the function they supply. Therefore, this group of resources indicates that description and meaning of the goods and services should be derived by their goals and deliverables rather than by usability-oriented concepts.

Similar to the focus on functionality, a further conceptualization of commons is based on the fundamental human rights they enable. The identification of such a function delivers a broader definition of commons as resources that incorporate inalienable individual rights and serve democratic citizenship [60-62]. On the contrary, the corpus of normative contributions centered on the dual notion of "access and use" reveals the complexity of commons' property regimes, institutional agreements, and management patterns [29], but offers no cogent specification about the reason that commons should be nondiscriminatory ("difficulty of exclusion" [2] (p. 645)) or which qualities can define them apart from divisibility, rivalry, and subtractability.

Thus, the definition of commons based on the standard economic concept of usability cannot deliver exhaustive and comprehensive knowledge of their nature. This is due not only to the heterogeneity of access and use conditions, which underlines the necessity of identifying an all-embracing class of resources, but mainly to the intrinsic impossibility of deriving from these actions what unifying function commons provide to individuals and collectivities.

\section{Commons and Identity}

The studies analyzed in Section 2 offer an overview of the differences in the implications that the notions of access and use entail when dealing with commons, and how complex this category of resources is when adopting such an economic perspective. On the one hand, this array of interpretations enables distinction between the proper and specific criteria to regulate and manage the commons. On the other hand, the focus on the concepts of nonexcludability and divisibility risks limiting the understanding of the nature of commons. 
While nonexcludability assumes that commons are fundamental for individuals and their communities, and thereby motivating no (or only partial) discriminatory access [13], no information can be inferred with respect to their essential contribution to human well-being. Somewhat similar limitations are associated with the second feature, divisibility. This economic concept and the derived rivalry remain confined to usability concerns and to modalities that should regulate the relationship between agent and commons [2,10]. Again, no further indication can be derived for understanding the benefits this category of resources can provide.

Based on these two long-established attributes of commons and on the related normative approach to govern access and use, the economic perspective suffers when asked to define commons. Indeed, the complexity and mutability of these resources require a reliable and comprehensive descriptive framework to understand, identify, and then regulate them. With this aim, the intrinsic nature of commons can be explained and defined only by their function. The conceptual advancement from usability to functionality implies extending the sphere of these resources to the human world.

A step in this direction is taken in the mentioned legal and political literature when defining commons as resources that make concrete the exercise of fundamental rights. However, it should be noted that a rights-based approach has some limitations in describing essential functions performed by resources with no legal protection (e.g., biodiversity), and in diagnosing large-scale commons (e.g., climate). Therefore, a comprehensive economic definition of commons should be derived by a broader notion of human well-being that the function is suitable to serve, an ultimate goal embracing the heterogeneity of the resources, as well as the diversity of individuals and their subjective and social complexity.

The concept of identity offers coherent insights for this purpose. Identity highlights what a person does or would do to be or become who she has reason to value. Identity emphasizes a dynamic evolution [63], a development process that can imply resorting to heuristics, mistakes, impositions, and conflicts [21]. Moreover, this mutable individual condition is often ambiguous and always characterized by a bundle of complementary and interwoven features (plural identities) [64]. This combination of identities determines two general integrated dimensions $[65,66]$, namely, individual and collective identity. These two spheres, which are "impossible to dissociate" [23] (p. 19), define the self-construction process in which social circumstances shape narratives for the development of the singularity [67].

When assuming identity as a measure of quality of life, its two components require attaining two related orders of conditions: dignity and membership. Different from the idea of minimum threshold [68], dignity envisages an evolutionary path of achieving progressive knowledge, consciousness, fulfillment, and capacity for choice [61]. In parallel, membership entails a proactive sense of linkage with others and nature [69], a world belongingness that implies interrelationships, citizenship, mutual inclusivity, reciprocity, and responsibility.

Based on the personal and social pillars, the concept of identity can provide a broad and dynamic definition of human well-being, while ascribing the goods and services functional to identity building on this wide class of resources. Any resource sustaining and developing the individual and/or collective dimensions of identity can be defined as an identity-oriented resource (examples are public resources and relational goods). Commons are part of this superordinate category of resources.

Identity describes what commons "do" [70] (p. 366) for human beings and, then, what a commons is [18]. In particular, identity defines the ultimate function commons deliver to humans and their communities by supporting the achievement of dignity and/or membership [12,15,59]. Any resource pertaining to the subordinate category of commons should serve at least one of these two identity-oriented values. This unifying identity-oriented function substantiates the understanding of commons as a whole.

Moreover, identity sheds light on the meaning of the two canonical economic characteristics of commons. As a top priority in individuals' agenda [21], choices of identity focus on achievable quality of life, represent "the most important economic decision" [22] (p. 717), and explain and motivate 
nondiscriminatory access to commons. The crucial role (multi-layered) identity plays in individual histories and evolution as individuals belonging to collectivities while implying possible conflicts or collaborations [21], accounts for the attribute of rivalry or antirivalry deriving from the distinctive divisibility of commons.

It should be noted that the identity-based function not only contributes to the knowledge of the nature of commons and to their definition but also enables detection of these resources and their potentialities. For instance, food does not exhaust its function once a certain amount of nutrients is delivered (food security; [1]) or the right to food access is fulfilled [71]. Rather, it involves a plurality of services, such as culture, awareness, lifestyle, dignity, and conviviality, which can enhance both the dimensions of identity. Nonetheless, water can contribute-as a unifying agent-to substantiate social identity (citizenship) [72]. Moreover, a remote endangered living organism provides biodiversity while substantiating and enriching the individuals' sense of belonging to the world (membership) [73]. Knowledge of the intrinsic identity-oriented nature of commons can further allow tackling their incipient drift by sharpening regulatory regimes [38] and adopting reliable governance patterns.

\section{Sustainability and Identity}

The definition of commons based on their identity-oriented functions (dignity and membership) highlights the crucial role they play among resources in the "ethical foundation of Sustainability Economics" and in the achievement of its "two normative goals of satisfaction of (i) individuals' needs and wants, and (ii) justice" [74] (p. 446). Similarly, the enhancement of the individual and collective identity that commons - in the proposed conceptualization—can provide shows how decisive this category of resources can be when the notion of sustainability transition is "grounded both at the societal and at the individual level" [75] (p. 212). Therefore, it is relevant to explore the principles of justice (the constitutive element of sustainability) and the goal of sustainability transition that depict the general conditions enabling commons to supply their identity-oriented functions.

Different accounts of justice have been developed, such as resource-based approaches (e.g., Rawls' theory of social primary goods [24]). In their generality, these approaches state that the metric of justice depends on the resources the economics agents hold while assuming that they have same beliefs, preferences, capacities, sense of responsibility, and goals (Rawlsian "moral powers," [24] (p. 58)). By contrast, according to Baumgärtner and Quaas [74], and Rauschmayer et al. [75] resource availability and efficient allocation alone are not sufficient means for well-being and social justice. For these purposes, addressing the normativity of sustainability should include factors that influence human development (e.g., concrete and latent opportunities), give substance to well-being assessments, and favor behavioral changes. This is noticeable when commons-in the proposed identity-oriented definition-are considered. Without careful consideration of the specificities of the individual self-construction process, the functions commons provide to support personal (dignity) and social (membership) identity would be limited or compromised.

This series of issues implies that sustainability and its achievement require suitable approaches not confined to resource-centered schemes and, in turn, that commons can deploy their identity-oriented functions only if a "radical transformation towards a sustainable society" [76] (p. 1) is pursued. Dealing with intra- and intergenerational justice, sustainability transition and its normativity have to recognize the diversity that characterizes individuals. This preliminary assumption is a constitutive element of the capability approach (CA) [77,78]. In the CA individualistic vision, people's objectives to attain quality of life are indeed confined to neither needs nor endowments $[70,79,80]$. Instead, this broader approach to the goal human beings seek embraces both achievement processes and opportunities (i.e., actual and potential functioning) and altruistic motivations derived from the heterogeneity of human beings [81-83].

It is in particular in the individual's faculty of being able and free to choose (capability) what to do and be that the CA recognizes not only the instrument (the "causal power" [82] (p. 3)) through which a person should evaluate and deliberate, but also the constitutive element of human 
well-being [84-87]. Because of its intrinsic value [88], freedom of choice (i.e., the basic freedom to choose among options according to one's own judgment values) measures the goal of human development and of sustainability [26,89], the notions of which are then expanded when compared to the related need-centered definitions [74,90-92]. Even if the CA were not a complete justice theory [93] (p. 337), a number of studies discuss and supplement the descriptive (ontological, $[74,82]$ ) and prescriptive $[78,86,92]$ contributions it delivers to the assessment of well-being and sustainability by analyzing its implications and challenges. In particular, the following three intertwined issues are the major shortcomings of the CA that the literature highlights: its individualistic primacy, static evaluative conception, and lack of uncertainty analysis.

With regard to the emphasis the CA places on individuals' freedom, the framework takes into account not only the personal but also the contextual conditions ("conversion factors") [94] (p. 34) that can limit the opportunities, but it does not fully describe the "interactive relationship between individuals" [95] (p. 403). While Robeyns [78] (p. 108) argues that the CA contemplates an "ethical individualism" and some authors propose the notion of collective capability $[95,96]$, the CA subordinates the collective dimension of freedom of choice to the privileged individual level $[75,91,97,98]$.

Concerning the static assessment of (well-being) freedom, the CA's idea of comparative choice between alternative sets is based on current individual values in which time concerns are not envisaged [86,92,99]. Lessman and Rauschmayer [91] further suggest that the lack of systemic analysis implies objective difficulty in considering the dynamic impacts a decision provokes on the same person or others' well-being.

Both shortcomings evoke the uncertainty intrinsic to evaluative activities and sustainability, while underlying the not entirely adequate analysis CA provides [81]. On the one hand, emotions, risk preferences, and complex interactions can strongly affect the current individual use of basic freedom, as inducing resort to heuristics often leads to undesired outcomes [91,100]. On the other hand, dynamic factors, such as values and preferences dependent upon time, as well as mutable conditions can influence and hinder the freedom of choice of future generations too [74,82]. Indeed, the three drawbacks determine noticeable implications on the CA-based concept of sustainability as "substantive freedom and capabilities of people" [26] (p. 251). These issues further suggest that the freedom of choice the CA proposes as a foundation and evaluative criterion of well-being and the goal of sustainability might not be a broad enough category to ensure durable human development.

During their lifetimes, in fact, individuals experience evolving personal processes that influence their emotions and values (adaptive preferences) [101], their perception of the environment and responsibility [102], their idea of well-being, and thereby their decisions ("becoming") [99] (p. 3). In some circumstances, this process can imply a misuse of freedom of choice driving detrimental effects on the individual or other people's quality of life. This is the case in which not yet acquired mature beliefs, solid principles, or skills, the loss of suitable motivations, or emotions can mislead the evaluative exercise and the actual and potential functioning [78] (p. 102). For instance, a shortsighted or unaware person can intend to defend or improve her own standard of living by exerting her agency (e.g., insecure driving) or refusing an opportunity (e.g., vaccination or cognition of dreadful social events), while the outcome can imply a worse-off individual condition.

Moreover, freedom might not be a fully appropriate measure of well-being when inability to choose occurs (i.e., unconnected preference relation; [70]). Because of the lack of individual characteristics (e.g., knowledge or awareness) or the complexity of the subject (e.g., the environmental issues of biodiversity or landscape), a person might be unable to use or disinterested in exercising some capabilities. When the omitted (immediate or counterfactual) choice provokes negative impacts on collectivity, feedbacks can affect individual well-being too (echoing Sen [70] (p. 66): "An act of choice ... is, in a fundamental sense, always a social act," it could be stated that a choice is always influenced and influences the society and, then, that an act of no choice is a social act as well). 
A conflict emerges: unwise perception or assessment of quality of life as well as the option of no choice can be coherent with the freedom of choice, but can directly or indirectly lead to restriction of the same freedom. In these circumstances, the informational space freedom delivers for evaluating quality of life suffers from temporal and spatial limitations. Instead, the influences that individual evolutionary process and interpersonal relationships exert on quality of life should be assessed. Therefore, it seems opportune to refine the concept of freedom of choice and further extend its constitutive contribution to human development. For this purpose, the notion of identity (Section 3) as the foundation of human well-being and the goal of sustainability can offer suitable hints.

In particular, the two integrated spheres of identity-singularity and sociality-emphasize the dynamics and collective dimensions of well-being commons should provide. On the one hand, singularity reflects the agent's personal evolution and multi-layered identity, and indicates that the current and prospective individual conditions should enter into the evaluative exercises. Not only does the diversity of human beings matter but also the diversity within the human being (within individuals). This extension of the CA's functioning through temporal information describes quality of life in the wider terms of dignity (fulfillment and awareness) to be pursued also in specific circumstances (e.g., vaccination) when contrary to myopic individual choices. On the other hand, sociality stresses the role that interactions among human beings and with nature play in shaping the individual and collective quality of life. While freedom of choice admits abstention, membership might require attention on no-choice options-when these risk weakening well-being-and expansion of the informational space. From this perspective, social identity depicts a more open-ended objective, which includes relationship, inclusivity, knowledge, and responsibility.

This identity-oriented view not only coherently causes the evolution of the CA framework (and the related definition of sustainable freedom [5]) but also allows widening the goal of sustainability transition $[71,82]$ to be pursued as a condition for the effective functionality of commons. Indeed, both singularity and sociality suggest in unison with the CA's concepts of potential functioning, achievements, and conversion factors that heterogeneities [77], processes, and interactions are relevant elements to the topic.

While broadening the assessment space of quality of life, sustainable identity describes the essential goal of sustainability and human development on the basis of an ethical notion that supplies "the motivation to act" [103] (p. 191) and a ground for substantive analysis and interventions.

\section{Conclusions}

This study offers an economic perspective on the notions of commons and sustainability with the purpose of contributing to the current descriptive and normative approaches, and outlining more comprehensive conceptual frameworks. Indeed, while commons are usually identified through standard usability criteria (nonexclusivity and rivalry), in the field of sustainability, significant acquisitions based on the notion of freedom of choice have been proposed by the CA and a large body of inspired literature. However, in terms of dealing with the complexity of the analyzed subjects, the state of the art recognizes some conceptual and operational drawbacks. The diversity among human beings, the multiple and mutable expression of the individual personality, the growing influence of social interactions, as well as the composite and mutable spectrum of resources underline the need to refer to more exhaustive knowledge and descriptions of these phenomena.

With this aim, this study contributes to the notion of identity as a consistent key both to describe the instruments (what is a commons?) relevant to human development, and to prescribe the related goal of sustainability (what is to be sustained?). With regard to commons, the concepts of identity and its two intertwined dimensions (individual and collective identity) allow us to overcome the canonical interpretation focused on regulatory and managerial vision, to explain and generalize the economic attributes-nondiscriminatory access and rivalrous use — of commons, and to center their definition on the identity-oriented functions (dignity and membership) that they exert. Concerning sustainability, identity further broadens and refines the CA's notions of freedom of choice and sustainable freedom 
by considering dynamic analysis and collective level as essential attributes of a wider informational space used to assess human well-being and development. To these ends, the identity-based concepts of dignity and responsibility define the general goal of sustainability transition (sustainable identity) to be pursued to enable commons to exert their identity-oriented functions.

While identity delivers a wider notion of commons and sustainability that can describe their complexity and evolution, elements of uncertainty persist in conditioning the evaluative exercises. The expansion of conceptual frameworks by design implies difficulties in substantiating appropriate measurements of individual advantage and practical initiatives. Therefore, it must be underlined that the identity-based approach provides a general (ontological) reference scheme for the definition of commons and the goal of sustainability, the contextualization of which requires consideration for the affecting temporal and social variables, further research and empirical analysis, and ultimate political evaluations.

Acknowledgments: Special thanks go to the anonymous referees.

Author Contributions: Marco Setti conceived and designed the research and wrote Sections 1 and 3, Sections 4 and 5; Matteo Garuti wrote Section 2.

Conflicts of Interest: The authors declare no conflict of interest.

\section{References}

1. Hess, C. Mapping New Commons. In Proceedings of the Twelfth Biennial Conference of the International Association for the Study of the Commons, Cheltenham, UK, 14-18 July 2008.

2. Ostrom, E. Beyond Markets and States: Polycentric Governance of Complex Economic Systems. Am. Econ. Rev. 2010, 100, 641-672. [CrossRef]

3. Baerlein, T.; Kasymov, U.; Zikos, D. Self-governance and sustainable common pool resource management in Kyrgyzstan. Sustainability 2015, 7, 496-521. [CrossRef]

4. Karanikolos, M.; Mladovsky, P.; Cylus, J.; Thomson, S.; Basu, S.; Stucker, D.; Mackenbach, J.; McKee, M. Financial crisis, austerity, and health in Europe. Lancet 2013, 381, 1323-1331. [CrossRef]

5. Greco, M.G.; Floridi, L. The tragedy of the digital commons. Ethics Inf. Technol. 2004, 6, 73-81. [CrossRef]

6. Falk, A.; Fehr, E.; Fischbaker, U. Appropriating the Commons: A Theoretical Explanation, in The Drama of the Commons; The National Research Council: Washington, DC, USA, 2002; pp. 157-191.

7. Read, D.; van Leeuwen, B. Predicting Hunger: The Effects of Appetite and Delay on Choice. Organ. Behav. Hum. Decis. Process. 1998, 76, 189-205. [CrossRef] [PubMed]

8. Ostrom, E. Governing the Commons. The Evolution of Institutions for Collective Action; Cambridge University Press: Cambridge, UK, 1990.

9. Kahn, E. The tragedy of the commons as an essentially aggregative harm. J. Appl. Philos. 2014, 31, 223-236. [CrossRef]

10. Hess, C.; Ostrom, E. Understanding Knowledge as a Commons: From Theory to Practice; MIT Press: Cambridge, MA, USA, 2007.

11. Charness, G.; Rabin, M. Understanding Social Preferences with Simple Tests. Q. J. Econ. 2002, 117, 817-869. [CrossRef]

12. Ibele, B.; Sandri, S.; Zikos, D. Endogenous versus exogenous rules in water management: An experimental cross-country comparison. Mediterr. Politics 2017, 22, 504-536. [CrossRef]

13. Bromley, D.W. Environment and Economy: Property Rights and Public Policy; Blackwell: Cambridge, MA, USA, 1991.

14. De Moor, T. What do we have in common? A comparative framework for old and new literature on the commons. Int. Rev. Soc. Hist. 2012, 57, 269-290. [CrossRef]

15. Bollier, D. Think like a Commoner: A Short Introduction to the Life of the Commons; New Society Publishers: Gabriola Island, BC, Canada, 2014.

16. Berge, E.; McKean, M. On the commons of developed industrialized countries. Int. J. Commons 2015, 9, 469-485. [CrossRef]

17. Euler, J. Conceptualizing the Commons: Moving Beyond the Goods-based Definition by Introducing the Social Practices of Commoning as Vital Determinant. Ecol. Econ. 2018, 143, 10-16. [CrossRef] 
18. Hess, C.; Ostrom, E. Ideas, Artifacts, and Facilities: Information as a Common-Pool Resource. Law Contemp. Probl. 2003, 66, 111-145.

19. Stavins, R.N. The problem of the commons: Still unsettled after 100 years. Am. Econ. Rev. 2011, 101, 81-108. [CrossRef]

20. Rifkin, J. The Zero Marginal Cost Society: The Internet of Things, the Collaborative Commons, and the Eclipse of Capitalism; Palgrave Macmillan: New York, NY, USA, 2014.

21. Bauman, Z. Identity: Conversations with Benedetto Vecchi; Polity Press: Cambridge, UK, 2004.

22. Akerlof, G.A.; Kranton, R.E. Economics and Identity. Q. J. Econ. 2000, 115, 715-733. [CrossRef]

23. Augé, M. Non-Places; Verso: London, UK, 1995.

24. Rawls, J. Justice as Fairness: A Restatement; Harvard University Press: Cambridge, MA, USA, 2001.

25. Robeyns, I.; Brighouse, H. Introduction: Social primary goods and capabilities as metrics of justice. In Measuring Justice. Primary Goods and Capabilities; Brighouse, H., Robeyns, I., Eds.; Cambridge University Press: Cambridge, UK, 2010; pp. 1-14.

26. Sen, A. The Idea of Justice; Allen Lane: London, UK, 2009.

27. Ostrom, E. Understanding Institutional Diversity; Princeton University Press: Princeton, NJ, USA, 2005.

28. Benkler, Y. Commons and Growth: The Essential Role of Open Commons in Market Economies. Univ. Chic. Law Rev. 2013, 80, 1499-1555.

29. Bromley, D.W. The Commons, Common Property, and Environmental Policy. Environ. Resour. Econ. 1992, 2, 1-17. [CrossRef]

30. Benkler, Y. The Political Economy of Commons. UPGRADE 2003, IV, 6-9.

31. Blomley, N. Enclosure, Common Right and the Property of the Poor. Soc. Legal Stud. 2008, 17, 311-331. [CrossRef]

32. Wall, D. The Commons in History; MIT Press: Cambridge, MA, USA, 2014.

33. Lessig, L. Code and the Commons. In Proceedings of the Conference on Media Convergence, New York, NY, USA, 9 February 1999.

34. Aitchison, J.; Gadsden, G. Common Land. In Agriculture, Conservation and Land Use: Law and Policy Issues for Rural Areas; Howarth, W., Rodgers, C., Eds.; University of Wales Press: Cardiff, UK, 1992; pp. 165-185.

35. Huppert, D.H. An overview of fishing rights. Rev. Fish Biol. Fish. 2005, 15, 201-215. [CrossRef]

36. Casari, M. Emergence of Endogenous Legal Institutions: Property Rights and Community Governance in the Italian Alps. J. Econ. Hist. 2007, 67, 191-226. [CrossRef]

37. Vollan, B.; Ostrom, E. Cooperation and the Commons. Science 2010. [CrossRef] [PubMed]

38. Jyotishi, A.; Sivramkrishna, S.; Lahiri-Dutt, K. Gold mining institutions in Nilgiri-Wayanad: A historicalinstitutional perspective. Econ. Political Wkly 2017, 52, 57-63.

39. Benkler, Y. Open Access and Information Commons. In Oxford Handbook of Law and Economics: Private and Commercial Law; Francesco, P., Ed.; Oxford University Press: Oxford, UK, 2016; Volume 2.

40. Schlager, E.; Blomquist, W.; Tang, S.Y. Mobile flows, storage, and self-organized institutions for governing common-pool resources. Land Econ. 1994, 70, 294-317. [CrossRef]

41. Feeny, D.; Hanna, S.; McEvoy, A.F. Questioning the assumptions of the "tragedy of the commons" model of fisheries. Land Econ. 1996, 72, 187. [CrossRef]

42. Hagedorn, K. Can the Concept of Integrative and Segregative Institutions Contribute to the Framing of Institutions of Sustainability? Sustainability 2015, 7, 584-611. [CrossRef]

43. Kasymov, U.; Hamidov, A. Comparative Analysis of Nature-Related Transactions and Governance Structures in Pasture Use and Irrigation Water in Central Asia. Sustainability 2017, 9, 1633. [CrossRef]

44. Bromley, D.W. Environmental governance as stochastic belief updating: Crafting rules to live by. Ecol. Soc. 2012, 17, 14. [CrossRef]

45. Frank, R.H. The Frame of Reference as a Public Good. Econ. J. 1997, 107, 832-847. [CrossRef]

46. Vasstrom, M. Rediscovering nature as commons in environmental planning: New understandings through dialogue. Int. J. Commons 2014, 8, 493. [CrossRef]

47. Tegoni, C.; Mulazzani, L.; Setti, M. Water governance under uncertainty: The case study of Users' Associations in Lebanon. New Medit 2016, 1, 62-71.

48. Ostrom, E. The Challenge of Common-Pool Resources. Environment 2008, 50, 8-20. [CrossRef]

49. Vatn, A.; Vedeld, P. Fit, interplay, and scale: A diagnosis. Ecol. Soc. 2012, 17, 12. [CrossRef] 
50. Zikos, D.; Roggero, D. The Patronage of Thirst: Exploring Institutional Fit on a Divided Cyprus. Ecol. Soc. 2012, 18, 25. [CrossRef]

51. Nussbaum, M. The Fragility of Goodness: Luck and Ethics in Greek Tragedy and Philosophy; Cambridge University Press: New York, NY, USA, 2001.

52. Sacco, P.L.; Vanin, P.; Zamagni, S. The Economics of Human Relationships. In Handbook on the Economics of Giving, Reciprocity and Altruism; Kolm, S.C., Ythier, J.M., Eds.; North-Holland: Amsterdam, NL, USA, 2006; pp. 695-730.

53. Berge, E. Protected Areas and Traditional Commons: Values and Institutions. Nor. J. Geogr. 2006, 60, 65-76. [CrossRef]

54. Moss, T. Spatiality of the Commons. Int. J. Commons 2014, 8, 457-471. [CrossRef]

55. Weber, S. The Success of Open Source; Harvard University Press: Cambridge, MA, USA, 2004.

56. Pieraccini, M. Democratic legitimacy and new commons: Examples from English protected areas. Int. J. Commons 2015, 9, 552. [CrossRef]

57. Bollier, D.; Helfrich, S. The Wealth of the Commons: A World beyond Market and State; Levellers Press: Amherst, MA, USA, 2012.

58. Shaw, M. Learning from The Wealth of the Commons: A review essay. Community Dev. J. 2014, 49, i12-i20. [CrossRef]

59. Mies, M. No commons without a community. Community Dev. J. 2014, 49, i106-i117. [CrossRef]

60. Dupré, L. The Common Good and the Open Society. Rev. Politics 1993, 55, 687-712. [CrossRef]

61. Rodotà, S. Il Diritto di Avere Diritti; Laterza: Bari, Italy, 2013.

62. Veca, S. L'idea dei beni comuni e i suoi rapporti con la giustizia sociale. In Beni Comuni e Cooperazione; Sacconi, L., Ottone, S., Eds.; Il Mulino: Bologna, Italy, 2015.

63. Hernández, B.; Carmen Hidalgo, M.; Salazar-Laplace, M.E.; Hess, S. Place attachment and place identity in natives and non-natives. J. Environ. Psychol. 2007, 27, 310-319. [CrossRef]

64. Sen, A. Identity and Violence. The Illusion of Destiny; W.W. Norton \& Company: New York, NY, USA; London, UK, 2006.

65. Bauman, Z. Voglia di Comunità; Laterza: Bari, Italy, 2007.

66. Akerlof, G.A.; Kranton, R.E. Identity Economics. How Our Identities Shape Our Work, Wages and Well-Being; Princeton University Press: Princeton, NJ, USA, 2010.

67. Kwame, A.A. The Ethics of Identity; Princeton University Press: Princeton, NJ, USA, 2005.

68. Nussbaum, M. Frontiers of Justice: Disability, Nationality, Species Membership; Belknap Press: Cambridge, MA, USA, 2006.

69. Mosimane, A.W.; Breen, C.; Nkhata, B. Collective Identity and Collective Action in the Management of Common Pool Resources: A Case Study of Doro! Nawas Conservancy in Namibia. Int. J. Commons 2012, 6, 344-362. [CrossRef]

70. Sen, A. Choice, Welfare and Measurement; Basil Blackwell: Oxford, UK, 1982.

71. Rundgren, G. Food: From Commodity to Commons. J. Agric. Environ. Ethics 2016, 29, 103-121. [CrossRef]

72. Zikos, D.; Sorman, A.H.; Lau, M. Beyond water security: Asecuritisation and identity in Cyprus. Int. Environ. Agreem. Politics Law Econ. 2015, 15, 309-326. [CrossRef]

73. Van Vugt, M. Averting the Tragedy of the Commons: Using Social Psychological Science to Protect the Environment. Curr. Dir. Psychol. Sci. 2009, 18, 169-173. [CrossRef]

74. Baumgärtner, S.; Quaas, M. What is sustainability economics? Ecol. Econ. 2010, 69, 445-450. [CrossRef]

75. Rauschmayer, F.; Bauler, T.; Schäpke, N. Towards a thick understanding of sustainability transitions-Linking transition management, capabilities and social practices. Ecol. Econ. 2015, 109, 211-221. [CrossRef]

76. Grin, J.; Rotmans, J.; Schot, J. Transitions to Sustainable Development; Routledge: London, UK, 2010.

77. Sen, A. Inequality Reexamined; Oxford University Press: Oxford, UK, 1992.

78. Robeyns, I. The capability approach: A theoretical survey. J. Hum. Dev. Capab. 2005, 61, 93-117. [CrossRef]

79. Sen, A. Rational fools: A critique of the behavioral foundations of economic theory. Philos. Public Aff. 1977, $V I, 317-344$.

80. Anand, S.; Sen, A. Human development and economic sustainability. World Dev. 2000, 28, $2029-2049$. [CrossRef]

81. Ballet, J.; Bazin, D.; Dubois, J.-L.; Mahieu, F.-R. A note on sustainability economics and the capability approach. Ecol. Econ. 2011, 70, 1831-1834. [CrossRef] 
82. Martins, N. Sustainability economics, ontology and the capability approach. Ecol. Econ. 2011, 72, 1-4. [CrossRef]

83. Martins, N. The place of the capability approach within sustainability economics. Ecol. Econ. 2013, 95, 226-230. [CrossRef]

84. Sen, A. Development as Freedom; Knopf: New York, NY, USA, 1999.

85. Sen, A. Sustainable development and our responsibilities. Not. Politeia 2010, 26, 129-137.

86. Ballet, J.; Koffi, J.-M.; Pelenc, J. Environment, justice and the capability approach. Ecol. Econ. 2013, 85, $28-34$. [CrossRef]

87. Pelenc, J.; Ballet, J. Strong sustainability, critical natural capital and the capability approach. Ecol. Econ. 2015, 112, 36-44. [CrossRef]

88. Sen, A. Freedom of Choice: Concept and Content. Eur. Econ. Rev. 1988, 32, 269-294. [CrossRef]

89. Sen, A. The Ends and Means of Sustainability. J. Hum. Dev. Capab. 2013, 14, 6-20. [CrossRef]

90. WCED-World Commission for Environment and Development. Our Common Future; Oxford University Press: Oxford, UK, 1987.

91. Lessmann, O.; Rauschmayer, F. Re-conceptualizing sustainable development on the basis of the capability approach: A model and its difficulties. J. Hum. Dev. Capab. 2013, 14, 95-114. [CrossRef]

92. Demals, T.; Hyard, A. Is Amartya Sen's sustainable freedom a broader vision of sustainability? Ecol. Econ. 2014, 102, 33-38. [CrossRef]

93. Sen, A. Elements of a theory of human rights. Philos. Public Aff. 2004, 32, 315-356. [CrossRef]

94. Griewald, Y.; Rauschmayer, F. Exploring an environmental conflict from a capability perspective. Ecol. Econ. 2014, 100, 30-39. [CrossRef]

95. Ibrahim, S.S. From individual to collective capabilities: The capability approach as a conceptual framework for self-help. J. Hum. Dev. 2006, 7, 397-416. [CrossRef]

96. Pelenc, J.; Bazile, D.; Ceruti, C. Collective capability and collective agency for sustainability: A case study. Ecol. Econ. 2015, 118, 226-239. [CrossRef]

97. Ferraro, E.; Reid, L. On sustainability and materiality. Homo faber, a new approach. Ecol. Econ. 2013, 96, 125-131. [CrossRef]

98. Meijers, F.; Lengelle, R.; Kopnina, H. Environmental Identity and Natural Resources: A Dialogical Learning Process. Resources 2016. [CrossRef]

99. Comim, F. Capability Dynamics: The Importance of Time to Capability Assessments, Personal Communication at the 3rd Conference on the Capability Approach; University of Pavia: Pavia, Italy, 2003.

100. DellaVigna, S. Psychology and Economics: Evidence from the Field. J. Econ. Lit. 2009, 47, 315-372. [CrossRef]

101. Nussbaum, M. Women and Human Development: The Capabilities Approach; Cambridge University Press: New York, NY, USA, 2000.

102. Macleod, C.M. Primary goods, capabilities, and children. In Measuring Justice. Primary Goods and Capabilities; Brighouse, H., Robeyns, I., Eds.; Cambridge University Press: Cambridge, UK, 2010; pp. 174-192.

103. Jamieson, D. Sustainability and beyond. Ecol. Econ. 1998, 24, 183-192. [CrossRef]

(C) 2018 by the authors. Licensee MDPI, Basel, Switzerland. This article is an open access article distributed under the terms and conditions of the Creative Commons Attribution (CC BY) license (http:/ / creativecommons.org/licenses/by/4.0/). 